\title{
PERAN KOPERASI UNIT DESA (KUD) DALAM MENINGKATKAN KESEJAHTERAAN ANGGOTA MELALUI PROGRAM KETERAMPILAN MENGOLAH MAKANAN
}

\author{
Nurain Karnain, Misran Rahman \\ Pascasarjana Universitas Negeri Gorontalo \\ nurainkarnain28@gmail.com
}

Received: 12 Desember 2019; Revised: 20 Desember 2019; Accepted: 3 Januari 2020

\begin{abstract}
ABSTRAK
Penelitian ini bertujuan untuk memperoleh gambaran tentang Peran Koperasi Unit Desa (KUD) dalam meningkatkan kesejahteraan anggota melalui keterampilan mengolah makanan di Kecamatan Kota Utara Kota Gorontalo. Untuk mendapatkan jawaban terhadap permasalahan di atas, peneliti menggunakan metode kualitatif, teknik pengumpulan data dalam bentuk observasi, dokumentasi, dan teknik wawancara. Hasil penelitian ini menunjukan bahwa Peran Koperasi Unit Desa (KUD) Indah Jaya dalam meningkatkan kesejahteraan anggota melalui program keterampilan mngolah makanan besar peranannya, hal ini dilihat dari: 1). Peran koperasi dalam mempersatukan taraf hidup anggota, yaitu koperasi selalu melakukan pertemuan dengan pengurus, karyawan, dan anggota dengan dinas instansi terkait antara lain dinas tenaga kerja dan koperasi. 2). Peran koperasi dalam mempertinggi taraf hidup anggota, setiap anggota koperasi khususnya anggota mengolah mengolah makanan masih berkesan kurang baik. 3). Peran koperasi dalam membina kelangsungan hidup anggota, pihak koperasi selalu mengadakan pembinaan dengan anggota mengolah makanan, pembinaan tersebut bertujuan untuk meningkatkan kesejahteraan anggota khususnya anggota perajin mengolah makanan.
\end{abstract}

Kata Kunci: Peran Koperasi, Peningkatkan Kesejahteraan Anggota.

\section{PENDAHULUAN}

Masyarakat merupakan salah satu komunitas yang ada di wilayah atau di daerah, dan umumnya masyarakat itu dalam upaya meningkatkan taraf hidup dan kesejahteraan, mereka melakukan berbagai aktivitas kegiatan berupa bertani, Pengrajin dan kegiatankegiatan lainnya. Dengan melihat kondisi masyarakat yang ada di wilayah tersebut maka dibutuhkan suatu lembaga untuk melakukan pembinaan dan pelatihan agar masyarakat benar-benar terarah dan kesejahteraan mereka mengalami peningkatan pendapatan ekonomi masyarakat. Sehubungan dengan hal tersebut masyarakat yang ada di wilayah Kecamatan Kota Utara Kota Gorontalo bergabung dalam suatu lembaga koperasi (KUD).

Koperasi Unit Desa (KUD) Indah Jaya pada dasarnya merupakan suatu proses, karena koperasi merupakan suatu kegiatan menuju kearah pertumbuhan dan perkembangan. Sehubungan dengan hal tersebut perlu ditingkatkan kesadaran masyarakat dan kemampuan masyarakat untuk berkoperasi serta mengembangkan koperasi tersebut dengan cara mengikuti penyuluhan ataupun seminar serta pembinaan tentang berkoperasi.

Koperasi Unit Desa (KUD) Indah Jaya merupakan salah satu koperasi yang ada di Kota Gorontalo. Wilayah kerja Koperasi Kota Gorontalo dan khususnya Kecamatan 
Kota Utara. Jumlah anggota Koperasi Unit Desa (KUD) Indah Jaya 250 orang. Anggota koperasi terdiri dari petani, dan perajin pembuat kue dan makanan.Unit-unit usaha yang ada di Koperasi Unit Desa (KUD) Indah Jaya yaitu unit usaha gilingan padi (pertanian), unit usaha simpan pinjam, unit usaha kerajinan mengolah makanan.

Dari unit-unit usaha yang ada di Koperasi Unit Desa (KUD) Indah Jaya yang menarik bagi peneliti yaitu unit usaha keterampilan mengolah makanan, dalam hal ini meliputi membuat kue dan makanan, hal inilah yang menjadi masalah utama di Koperasi Unit Desa (KUD) Indah Jaya. Dalam menjalankan unit usaha ini perajin mengalami berbagai masalah terutama dalam hal kurangnya permodalan bagi para perajin serta pemasaran hasil produksi kue dan makanan, hal inilah yang menjadi masalah pokok yang dihadapi oleh para perajin. Kehadiran Koperasi Unit Desa (KUD) Indah Jaya di tengah-tengah para perajin khususnya anggota yang telah bergabung sebagai anggota koperasi, memberi solusi kepada anggota koperasi dalam rangka untuk meningkatkan kesejahteraan anggota. Koperasi Unit Desa (KUD) Indah Jaya dalam mengelola unit usaha membuat kue dan makanan bertindak sebagai pemasar dan anggota koperasi yang menyiapkan jenis kue dan makanan yang akan dipasarkan. Untuk menunjang kelancaran unit usaha, Koperasi Unit Desa (KUD) Indah Jaya membantu perajin anggota dalam bentuk modal kerja berupa bahan-bahan yang digunakan untuk mengolah makanan.

Dari segi pemasaran sering Koperasi Unit Desa (KUD) Indah Jaya mengalami masalah akibat kurang profesionalnya perajin membuat kue dan makanan. Hal ini terbukti dari sekian banyak anggota perajin mengolah makanan tidak memperhatikan jenis-jenis kue dan makanan yang dibuat, serta tidak ada koordinasi masing-masing perajin atau anggota, sehingga sering terjadi kue dan makanan yang dipasarkan atau dijual jenisnya sama dan tidak dapat dipasarkan, akibatnya merugikan perajin membuat kue dan makanan tersebut.

Dengan melihat kondisi tersebut perlu adanya perencanaan menajemen dalam menjalankan unit usaha, sehingganya diharapkan kepada pengurus Kopeasi Unit Desa (KUD) Indah Jaya untuk melakukan terobosan melalui program pendidikan dan pelatihan serta pembinaan terhadap anggota perajin mengolah makanan melalui pembinaan pendidikan dan pelatihan setiap anggota akan diatur dan dikelompokan agar lebih berkreasi dalam menciptakan jenis kue yang baru, sehingga anggota perajin mengolah makanan tidak terkesan hanya ikut-ikutan saja.

\section{KAJIAN TEORITIS}

\section{A. Pengertian Koperasi}

Koperasi sebagai bentuk badan usaha bersama yang berjuang bersama dalam bidang ekonomi dengan menempuh jalan yang tepat dan mantap dengan tujuan membebaskan diri para anggotanya dari kesulitan-kesulitan ekonomi. koperasi adalah suatu bentuk peraturan dan tujuan tertetu pula, perusahaan yang didirikan oleh orangorang tertentu, untuk melakukan kegiatan-kegiatan tertentu berdasarkan atas asas kekeluargaan. (Subandi, 2015:18).

Menurut Soeriaatmaja: "Koperasi sebagai suatu perkumpulan dari orang-orang yang atas dasar persamaan derajat sebagai manusia dengan tidak memandang haluan agama dan politik dan secara sukarela masuk untuk sekedar memenuhi kebutuhan bersama yang bersifat kebendaan atas tanggungan bersama". (Andjar Pachta W, dkk, 2012: 19) 
Menurut H.E Erdman: "Koperasi adalah usaha bersama, merupakan badan shukum, anggota ialah pemilik dan yang menggunakan jasanya dan mengembalikan semua penerimaan diatas biayanya kepada anggota sesuai dengan transaksi yang mereka jalankan dengan koperasi”. (Subandi, 2015: 18)

Dari pendapat para ahli diatas dapat disimpulkan bahwa koperasi merupakan suatu organisasi yang dibentuk untuk membantu setiap individu untk dapat melakukan kegiatan-kegiatan dalam usaha bersama.

\section{B. Fungsi dan Peran Koperasi (KUD)}

Menurut Sumarsono, dalam buku Manajeman Koperasi bahwa fungsi dapat diartikan sebagai alat untuk mencapai tujuan dan tujuan ini harus jelas dan tegas. Koperasi pada hakikatnya hanyalah merupakan alat untuk mencapai tujuan. Apabila koperasi yang memberikan jasanya maka kita yang harus memelihara dan membayar biaya yang dikeluarkan. Fungsi koperasi dalam hal ini memberikan jasa kepada anggota dan angota mengeluarkan biaya untuk menggantinya. Dengan demikian koperasi pada dasarnya tidak mendapat manfaat apa-apa, akan tetapi anggota yang menerima manfaat tersebut.

Dalam hubungannya itu efesiensi koperasi diukur dari tingkat pemberian jasanya. Tingkat efesiensi koperasi ini akan tergantung kepada bagaimana penggunaan dan memelihara koperasi. Kalau koperasi berfungsi baik, maka baik pula jalannya.

Dalam rangka mewujudkan fungsi tersebut diatas, koperasi/KUD mempunyai peranan yang sangat penting dalam peningkatan tingkat pendapatan masyarakat terutama anggota yang tidak terpisahkan dari fungsi-fungsi koperasi/KUD yang telah dijelaskan diatas.

Pandangan tentang koperasi dalam masyarakat dapat dikelompokan dalam tiga aliran yaitu, Aliran Yardstick: Menurut pandangan ini, peranan koperasi pada dasarnya hanyalah sebagai tolak ukur, dalam arti sebagai penetralisir keburukan yang timbul oleh sistem perekonomian kapitalis. Aliran Sosialis: Aliran ini memandang sistem perekonomian kapitalis sebagai asal mula penindasan terhadap rakyat banyak. Maka kehadiran koperasi didalam masyarakat kapitalis harus difungsikan sebagai kekuatan untuk mengganti sistem perekonomian kapitalis tersebut. Aliran Persemakmuran: Aliran ini dapat dikategorikan aliran tengah. Disatu pihak sebagai aliran Yardstick, aliran ini memandang sistem perekonomian kapitalis sebagai suatu sistem perekonomian yang harus dihancurkan, tetapi sebagaimana aliran sosialis, sepakat harus sistem perekonomian kapitalis pernah dikoreksi, namun tidak di seradikal aliran sosial. Menurut aliran ini, peran koperasi didalam masyarakat kapitalis tidak sekedar sebagai tolak ukur alat penawar, tetapi sebagai alternatif dari bentuk kerusakan kapitalis. Sebagai bentuk perusahaan alternatif, maka peranan koperasi harus terus ditingkatkan dan dikembangkan sebagai suatu gerakan masyarakat dalam mewujudkan masyarakat koperasi. (Subandi, 2015: 30)

\section{METODE PENELITIAN}

Peneliti menggunakan penelitian yang berbentuk kualitatif, metode yang digunakan dalam penelitian ini adalah metode deskriptif analisis, yaitu untuk mendapatkan gambaran yang jelas mengenai masalah yang diteliti, serta melakukan analisis terhadap data yang diperoleh melalui penelitian. Penelitian ini dilaksanakan di Koperasi Unit Desa (KUD) Indah Jaya Kecamatan Kota Utara Kota Gorontalo. Sumber data yang 
digunakan dalam penelitian ini adalah sumber data primer dan sumber data sekunder. Prosedur pengumpulan data yaitu peneliti menggunakan prosedur obserservasi, wawancara, dan dokumentasi. Analisis data yang digunakan dalam penelitian ini yaitu peneliti menggunakan analisis reduksi data dan analisis penyajian data.

\section{PEMBAHASAN}

Hasil penelitian ini menunjukan bahwa Koperasi Unit Desa (KUD) Indah Jaya merupakan suatu koperasi yang menjadi mata pencaharian bagi masyarakat di Kecamatan Kota Utara Kota Gorontalo, khususnya bagi para anggota, sehingga itu Koperasi Unit Desa (KUD) Indah Jaya memiliki peran penting untuk mempersatukan taraf hidup anggota, mempertingi taraf hidup anggota, dan membina kelangsungan hidup bagi anggota.

1. Peran Koperasi Unit Desa (KUD) dalam mempersatukan taraf hidup anggota:

Koperasi merupakan salah satu bentuk organisasi ekonomi yang dipilih oleh sebagian anggota masyarakat dalam rangka meningkatkan kemajuan ekonomi (rumah tangga) serta kesejahteraan hidupnya. Secara logika sederhana, orang akan memilih koperasi jika organisasi ekonomi tersebut dirasakan atau diyakini bisa mendatangkan manfaat lebih besar baginya dari pada bentuk organisasi ekonomi lain. Sebuah koperasi dikatakan berhasil atau sukses jika mampu mempersatuka taraf hidup anggota dan mensejahterakan anggotanya. (Diahstuti, 2011)

a. Melakukan Pertemuan

Berdasarkan hasil penelitian mengenai Koperasi Unit Desa (KUD) Indah Jaya melakukan pertemuan-pertemuan dengan pengelola, karyawan, dan

anggota yaitu belum baik, hal ini dilihat dari keikutsertaan anggota KUD Indah Jaya, khususnya anggota mengolah makanan yang masih sebagian besar jarang sekali mengikuti pertemuan-pertemuan tersebut.

Adapun solusi yang dapat diberikan yaitu pihak pengelola khususnya ketua dan bendahara lebih tegas lagi dalam menghadapi anggota-anggota mengolah makanan yang tidak sering hadir dalam pertemuan-pertemuan, dan jika perlu ketu KUD Indah Jaya memberikan sanksi tegas berupa pembatasan pinjaman modal untuk anggota yang tidak sering hadir dalam pertemuan, sanksi ini saya rasa dapat menjadi salah satu solusi dari permasalahan tersebut.

\section{b. Membuka Kelompok-kelompok Usaha}

Berdasarkan hasil penelitian mengenai Koperasi Unit Desa (KUD) Indah Jaya membuka kelompok-kelompok usaha yaitu sudah baik, hal ini dapat dilihat dari aktivitas keseharian anggota mengantarkan kue dan makanan di KUD Indah Jaya, namun ada juga anggota mengolah makanan yang belum baik karena mereka masih menjual kue dan makanan dengan jenis yang sama dengan anggota pembuat kue yang berbeda, sehingga membuat sering kali jualan tidak laku.

Adapun solusi yang dapat peneliti berikan kepada anggota KUD Indah Jaya khususnya anggota mengolah makanan yang usahanya belum baik yaitu seharusnya mereka lebih kreativ serta mengubah jenis-jenis kue dan makanan yang mereka jual agar tidak terjadi kesamaan jenis kue dan makanan dengan anggota lainnya. Kemudian solusi untuk pengelola KUD Indah Jaya agar dapat membuat peraturan 
untuk setiap anggota yaitu tidak boleh menitipkan jenis kue dan makanan yang sama. Solusi ini saya rasa dapat memberikan dampak yang positif terhadap masing-masing anggota.

\section{c. Menjalani Kelompok Usaha dengan Baik}

Berdasarkan hasil penelitian penulis yang diperoleh dari hasil wawancara dengan informan anggota perajin mengolah makanan telah menjalani kelompok usaha dengan baik. Hal ini terbukti bahwa usaha mereka telah mengalami perkembangan sehingga dapat memenuhi kebutuhan hidup.

Dengan perkembangan usaha tersebut anggota perajin mengolah makanan belum puas, sehingga anggota berupaya untuk mempertahankan bahkan lebih meningkatkan usaha yang telah mereka jalani. Adapun upaya-upaya yang mereka lakukan untuk mepertahankan yaitu untuk meningkatkan jenis-jenis kue serta makanan yang anggota buat sehingga hasil jualan mereka habis terjual.

\section{Peran Koperasi dalam Mempertinggi Taraf Hidup Anggota}

Koperasi berperan dapat meningkatkan pendapatan anggota dan menyediakan lapangan kerja bagi mereka yang bersedia bergabung dalam koperasi. Meningkatnya pendapatan berarti memungkinkan mereka untuk lebih banyak mencukupi kebutuhan hidupnya. Semakin tercukupinya kebutuhan hidup berarti taraf hidup anggotapun meningkat. (Sumarsono, 2004).

a. Berperan Aktif dalam Kelompok

Berdasarkan hasil penelitian yang diperoleh dari hasil wawancara dengan informan, terbukti bahwa peran aktif anggota perajin mengolah makanan berkesan kurang baik, hal ini disebabkan sebagian besar anggota perajin mengolah makanan di Koperasi Unit Desa (KUD) Indah Jaya tidak sering mengikuti pembinaan mengenai pendidikan dan keterampilan mengolah makanan yang telah diprogramkan oleh Koperasi Unit Desa (KUD) Indah Jaya, sehingga usaha mereka tidak berkembang dengan baik.

Untuk mengatasi hal tersebut upaya yang dilakukan oleh Koperasi Unit Desa (KUD) Indah Jaya yaitu mengsosialisasikan kepada anggota perajin mengolah makanan tentang manfaat ikut serta dalam pembinaan mengikuti pendidikan dan pelatihan keterampilan mengolah makanan.

\section{b. Peningkatan Taraf Hidup Anggota}

Berdasarkan hasil penelitian yang diperoleh dari hasil wawancara dengan informan, bahwa setiap anggota perajin mengolah makanan yang aktif mengalami peningkatan taraf hidup yang baik, hal ini dapat dilihat dari rasa percaya diri setiap anggota untuk bergabung dengan orang-orang baru serta percaya diri untuk lebih meningkatkan hasil jualan mereka. Untuk mempertahankan kondisi tersebut para perajin mengolah makanan berupaya untuk setiap jenis kue dan makanan yang dibuat selalu mempertahankan kualitas bahkan meningkatkan kualitas dari masing-masing jeis kue dan makanan yang dipasarkan di Koperasi Unit Desa (KUD) Indah Jaya. Hal ini dapat dibuktikan bahwa anggota perajin kue dan makanan yang aktif berpengaru terhadap peningkatan taraf hidup mereka.

c. Peningkatan Usaha 
Dari hasil penelitian penulis yang diperoleh dari wawancara dari informan terbukti bahwa dari jumlah anggota perajin membuat kue dan makan tidak semuanya mengalami peningkatan usaha dengan baik, tapi masih terdapat sebagian kecil anggota perajin mengolah makanan yang belum berkembang usahanya, atau perkembangan usaha dari perajin mengolah makanan terjadi pasang surut peningkatan usaha. Hal ini diakibatkan setiap anggota peraji mengolah makanan yang mengalami peningkatan usaha mereka aktif dan tekun dalam menjalankan usaha serta mereka membuat berbagai jenis kue dan makanan yang mereka pasarkan di Koperasi Unit Desa (KUD) Indah Jaya, sedangkan yang kurang mengalami peningkatan usaha akibat mereka mempertahankan jenis kue dan makanan yang mereka jual tidak bervariasi.

Untuk mengatasi anggota perajin mengolah makanan yang kurang mengalami peningkatan usahanya, Koperasi Unit Desa (KUD) Indah Jaya melakukan pembinaan kepada mereka terutama cara membuat jenis kue agar nasib mereka akan sejajar dengan anggota perajin mengolah makanan yang telahmengalami peninngkatan usahanya. Disamping itu, bagi para perajin yang telah mengalami peningkatan usaha, Koperasi Unit Desa (KUD) Indah Jaya berusaha untuk mempertahankan kualitas yang telah mereka capai, bahkan berusaha untuk meningkatkan hasil produksi yang akan dipasarkan.

\section{Peran Koperasi dalam Membina Kelangsungan Hidup Anggota}

Faktor pendidikan, pelatihan dan pembinaan merupakan bentuk implementasi dari pembinaan dari anggota koperasi secara empiris menjadi sarana untuk meningkatkan peran serta aktif anggota. Pengembangan sistem pendidikan, pelatihan dan pembinaan perkoperasian bagi anggota dan pengelola koperasi, calon anggota dan kader koperasi, terutama untuk menanamkan nilai-nilai dasar dan prinsip-prinsip koperasi dalam kehidupan koperasi yang mengatur secara jelas adanya pembagian tugas dan tanggung jawab antara pemerintah dan gerakan koperasi. (Sujianto, 2012)

\section{a. Pembinaan dari Instansi}

Dari hasil penelitian penulis yang diperoleh dari hasil wawancara dengan informan bahwa di Koperasi Unit Desa (KUD) Indah Jaya selalu ada pembinaan dan kerjasama yang baik dengan pihak instansi terkait berupa dinas koperasi dan dinas sosial tenaga kerja, khusus untuk anggota perajin mengolah makanan KUD Indah Jaya telah memprogramkan tentang pembinaan mengenai keterampilan mengolah makanan, namun tidak semua perajin mengolah makanan mengikuti pembinaan dari instansi tersebut, ada yang jarang mengikuti dan ada yang sama sekali tidak pernah mengikuti poembinaan tersebut.

b. Melibatkan Anggota dalam Pembinaan

Berdasarkan hasil penelitian yang diperoleh melalui hasil wawancara dengan informan, bahwa di Koperasi Unit Desa (KUD) Indah Jaya selalu melibatkan anggota dengan baik, namun tidak semua anggota mengolah makanan hadir dalam kegiatan pembinaan tersebut. Untuk mempertahankan hal ini diharapkan pada pengelola KUD Indah Jaya agar tetap mengadakan pembinaan tersebut walaupun masih ada juga anggota yang tidak hadir, dengan harapan pada hari berikutnya semua anggota dapat hadir mengikuti pembinaan tersebut. 


\section{c. Perkembangan Usaha Koperasi}

Berdasarkan hasil penelitian yang diperoleh dari hasil wawancara dengan informan bahwa pembinaan yang dilakukan belum berpengaruh baik terhadap perkembangan KUD Indah Jaya, hal ini disebabkan oleh ketidakaktifan anggota perajin mengolah makanan dalam mengikuti pembinaan, ada yang mengikuti pembinaan dengan baik dan ada juga yang tidak mengikutinya dengan serius, serta masih banyak anggota yang tidak sering hadir dalam kegiatan pembinaan tersebut.

Terkait dengan permasalahan di atas, maka solusi yang dapat peneliti berikan yaitu pihak pengelola KUD Indah Jaya maupun dinas instansi terkait harus lebih bekerjasama dan lebih kreatif dalam memberikan pembinaan, buat suatu yang unik yang dapat memancing anggota untuk bisa hadir dalam mengikuti pembinaan tersebut, misalnya disediakan uang duduk untuk setiap anggota yang hadir.

d. Kerjasama dengan Dinas Terkait

Berdasarkan hasil penelitian yang diperoleh dari hasil wawancara dengan informan bahwa pengurus maupun anggota KUD Indah Jaya belum merasakan kepuasan terhadap kerjasama yang dilaksanakan oleh Koperasi Unit Desa (KUD) Indah Jaya dengan dinas instansi terkait. Hal ini disebabkan karena masih banyak anggota perajin mengolah makanan yang belum dapat mengembangkan usaha kue dan makanan mereka.

Adapun solusi yang dapat diberikan peneliti dalam permasalahan di atas yaitu pihak instansi lebih meningkatkan lagi materi atau penyampaian-penyampain yang berhubungan dengan keterampilan mengolah makanan, agar anggota yang mengikuti pembinaan tersebut tidak merasa bosan serta dapat mengimplementasikan dalam keseharian mereka.

Dari hasil wawancara serta pembahasan di atas, jelas diketahui bahwa anggota perajin membuat kue dan makanan perlu diberikan motivasi serta dorongan tentang pentingnya mengikuti kegiatan pendidikan serta pembinaan untuk meningkatkan kualitas kue dan makanan yang anggota buat setiap hari, agar setiap anggota khususnya anggota perajin membuat kue dan makanan yang tidak berperan aktif dalam setiap kegiatan yang koperasi laksanakan dapat berubah serta dapat berperan aktif pada kegiatan koperasi. Hal ini dimaksudkan agar dapat berpengaruh juga pada peningkatan pendapatan anggota secara keseluruhan.

Dari hasil pembahasan di atas, jelas diketahui bahwa anggota perajin membuat kue dan makanan perlu diberikan motivasi serta dorongan tentang pentingnya mengikuti kegiatan pendidikan serta pembinaan untuk meningkatkan kualitas kue dan makanan yang anggota buat setiap hari, agar setiap anggota khususnya anggota perajin membuat kue dan makanan yang tidak berperan aktif dalam setiap kegiatan yang koperasi laksanakan dapat berubah serta dapat berperan aktif pada kegiatan koperasi. Hal ini dimaksudkan agar dapat berpengaruh juga pada peningkatan pendapatan anggota secara keseluruhan.

\section{KESIMPULAN}

Peran Koperasi Unit Desa (KUD) Indah Jaya dalam mempersatukan taraf hidup anggota, pihak pengelola selalu melaksanakan pertemuan-pertemuan dengan anggota, baik itu pertemuan mengenai sosialisasi mengenai pembinaan-pembinaan untuk anggota khususnya anggota perajin kue dan makanan, maupun pertemuan mengenai Rapat Anggota Tahunan (RAT). Koperasi Unit Desa (KUD) Indah Jaya membuka kelompok- 
kelompok usaha salah satunya yaitu unit usaha keterampilan mengolah makanan. Anggota perajin mengolah makanan yang selama ini aktif selalu menjalani kelompok usaha mereka dengan baik karena mengolah makanan sudah menjadi rutinitas anggota dalam keseharian mereka, sehingga anggota perajin mengolah makanan yang aktif mengalami perkembangan usaha dan penghasilan mereka juga ikut meningkat.

Peran Koperasi Unit Desa (KUD) Indah Jaya dalam mempertinggi taraf hidup anggota dilihat dari peran aktif dalam kelompok khususnya anggota perajin mengolah makanan masih berkesan kurang baik, hal ini disebabkan sebagian besar anggota perajin mengolah makanan di KUD Indah Jaya tidak sering mengikuti pembinaan mengenai pendidikan keterampilan mengolah makanan. Anggota yang aktif selalu mengalami peningkatan usaha serta peningkatan pendapatan yang berpengaruh positif pada perubahan rumah anggota, pendidikan bagi anak-anak anggota, serta kebutuhankebutuhan sehari-hari anggota perajin mengolah makanan, sedangkan anggota yang kurang berperan aktif tidak mengalami peningkatan dalam usahanya.

Koperasi Unit Desa (KUD) Indah Jaya dalam membina kelangsungan hidup anggota dapat dilihat dengan selalu mengadakan pembinaan-pembinaan dari instansi terkait seperti dinas tenaga kerja koperasi, dinas pertanian dan tanaman pangan, dinas perdagangan dan perindustrian, serta pembinaan pelatihan keterampilan mengolah makanan. Koperasi Unit Desa (KUD) Indah Jaya mengadakan pembinaan dengan instansi terkait bertujuan untuk meningkatkan kesejahteraan anggota khususnya anggota perajin mengolah makanan, sehingga dapat berpengaruh pada kelangsungan hidup setiap anggota. Dalam kegiatan pembinaan Koperasi Unit Desa (KUD) Indah Jaya selalu melibatkan anggota khususnya anggota perajin mengolah makanan, sebab di Koperasi Unit Desa (KUD) Indah Jaya pembinaan keterampilan mengolah makanan selalu diadakan, akan tetapi tidak semua anggota hadir untuk mengikuti pembinaan tersebut sehingga masih banyak anggota perajin mengolah makanan yang membuat jenis kue yang sama yang berdampak pada pendapatan atau penghasilan dari masingmasing anggota.

\section{DAFTAR PUSTAKA}

Diahastuti Rahayu. (2011). Peran Koperasi Dalam Meningkatkan Kesejahteraan masyarakat Pondok Pesantren Assalam. Jurnal Sosiologi, 11

Kartasapoetra G, (2005). Praktek Pengelolaan Koperasi. Jakarta: Rineka Cipta dan Bina Adiaksara.

Rosvinda Bunga. (2013). Peran Koperasi Terhadap Peningkatan Pendapatan Anggota. Jurnal Ilmiah Malang: Universitas Brawijaya. diakses 14 Juni 2017.

Subandi. (2015). Ekonomi Koperasi (Teori dan Praktik). Bandung: Alfabeta.

Sujianto E. Agus. (2012). Pengaruh Pendidikan, Pelatihan dan Penyuluhan Terhadap Partisipasi Anggota Koperasi Pondok Pesantren. Vol 6. 332

Sumarsono Sonny. (2004). Manajeman Koperasi (Teori dan Praktek). Yogyakarta: Graha Ilmu.

Undang-Undang Nomor 12 Tahun 1967 Tentang Perkoperasian. 